\title{
A PESTE DAS BEXIGAS NO BRASIL COLONIAL: TRAGÉDIA HISTÓRICA OU GENOCÍDIO? ${ }^{1}$
}

\section{Smallpox Plague In Colonial Brazil: Historical tragedy or genocide?}

\author{
Ronaldo Vainfas \\ Doutor pela USP \\ Professor da Pós-graduação em História da \\ Universidade do Estado do Rio de Janeiro (UERJ) e da \\ Universidade Federal do Rio Grande do Norte (UFRN) \\ https://orcid.org/0000-0003-0069-0374 \\ Email: rvainfas@terra.com.br
}

Recebido em: 13/07/2020

Aprovado em: 20/10/2020

\begin{abstract}
Resumo: $\mathrm{O}$ artigo é dedicado ao estudo do impacto da pandemia de varíola na população indígena do litoral brasileiro durante o século XVI. Ele oferece uma comparação entre a disseminação da varíola na América colonial e a da Peste Negra europeia no final da Idade Média. Discute a pandemia de varíola no contexto da colonização ibérica, principalmente a portuguesa. Analisa a hipótese da origem africana da varíola disseminada no Brasil. Também examina as evidências quantitativas sobre a mortalidade indígena, relacionando-a aos procedimentos adotados nas aldeias jesuítas. Por fim, avalia a relevância de conceitos como genocídio ou necropolítica para os estudos sobre a pandemia de varíola no século XVI.

Palavras-chave: Varíola, Indígenas, Genocídio.

Abstract: This article studies the impact the $16^{\text {th }}$ century smallpox pandemic had on the indigenous population of the Brazilian coast. It offers a comparison between the spread of smallpox in colonial America and the European Black Plague in the Late Middle Ages. It discusses the smallpox pandemic in the context of Iberian colonization, especially the Portuguese one. It analyzes the hypothesis of the African origin of the strain of smallpox spread in Brazil. It also examines quantitative evidence on native mortality, relating it to the procedures adopted in the Jesuit villages. Finally, it evaluates the relevance of concepts such as Genocide or Necropolitics for the studies on the smallpox pandemic in the 16th century.
\end{abstract}

Keywords: Smallpox, Native Brazilians, Genocide. 


\section{Introdução}

Em 1985, Jacques Le Goff organizou um livro intitulado As doenças têm história, baseado em dossiê número 74 da revista L'Histoire, Les Maladies ont une histoire. Um pequeno volume de 134 páginas com artigos curtos sobre diversas doenças, o impacto social de epidemias, as terapêuticas adotadas, vacinas contra bactérias ou vírus, os sentimentos coletivos; obra que adota a perspectiva da longa duração típica das mentalidades. Nesta altura, as mentalidades, como conceito, estavam em declínio. Eram criticadas por todos os lados, uns porque as rejeitavam por sua opção interclassista e por seu abandono da história total; outros porque, ao contrário, consideravam o conceito inconsistente do ponto de vista antropológico, uma vez que pensava a alteridade no tempo a partir de conceitos do século $\mathrm{XX}$, herdeiros do racionalismo cientificista. $\mathrm{O}$ britânico Stuart Clark publicou artigo emblemático contra a historiografia francesa das mentalidades a partir e um ponto de vista antropológico. (CLARK, 1983: p.65).

De todo modo, em 1985 Le Goff ainda considerava o conceito de mentalidades válido. $\mathrm{Na}$ apresentação deste livro, traduzido pela editora portuguesa Terramar no mesmo ano, escreveu "que a doença pertence não só à História dos progressos científicos e tecnológicos como também à História profunda dos saberes e das práticas ligadas às estruturas sociais, às representações, às mentalidades" (LE GOFF, 1991: p.8). Pretendia, de certo modo, desvincular a história das doenças da História da Ciência convencional, sem negá-la, é claro, mas para pensá-la no campo sociocultural.

As doenças têm história inclui artigos magistrais sobre as pestes na história ocidental, a exemplo da peste bubônica, da sífilis, da varíola. Examinam as epidemias ou pandemias que flagelaram as populações e provocaram, ora surtos místicos, ora esforços terapêuticos que deram enorme contribuição à medicina ocidental.

Atualmente, trata-se de um campo de pesquisa mundialmente consolidado, tanto na História da Ciência, que incorporou a perspectiva sociocultural em diversos trabalhos, quanto, por vocação, na História Cultural, devido à sua proximidade com a Antropologia. Na época em que saiu o citado livro, tudo isto ainda era novidade. Em pleno século XXI, no limiar de sua terceira década, o tema é de extraordinária atualidade, independentemente dos debates conceituais. O ano de 2020 inaugurou uma das maiores pandemias da história, provocada por um vírus até então desconhecido. 
Responsável por milhões de infectados e milhares de mortos em escala multicontinental. Uma tragédia mundial, um flagelo sobre o qual os historiadores podem contribuir para uma reflexão científica ou, quando menos, humanista.

\section{Peste negra, pandemia dos brancos}

Na obra organizada por Le Goff, o tema é abordado por Robert Delort: Que a peste seja o rato. Eis o título do artigo sobre a Peste Negra que flagelou a Europa no século XIV, reincidindo, em menor escala no século XV, além de - convém lembrar ter assolado várias regiões asiáticas na mesma época.

A variante da pandemia que assolou a Europa foi a peste bubônica, que Delort caracterizou como a mais devastadora pandemia da história humana, focada na vasta Eurásia, com letalidade na escala de milhões de pessoas. Segundo Delort, o pico da peste na Europa ocorreu entre 1347 e 1351, quando cerca de 1/3 da população perdeu a vida, asfixiada, nos casos terminais, além de molestados por várias feridas no corpo. Alguns autores mencionam $40 \%$ ou mais entre as vítimas fatais da peste negra na Europa. O que tais frações ou percentuais significam em termos de vidas humanas?

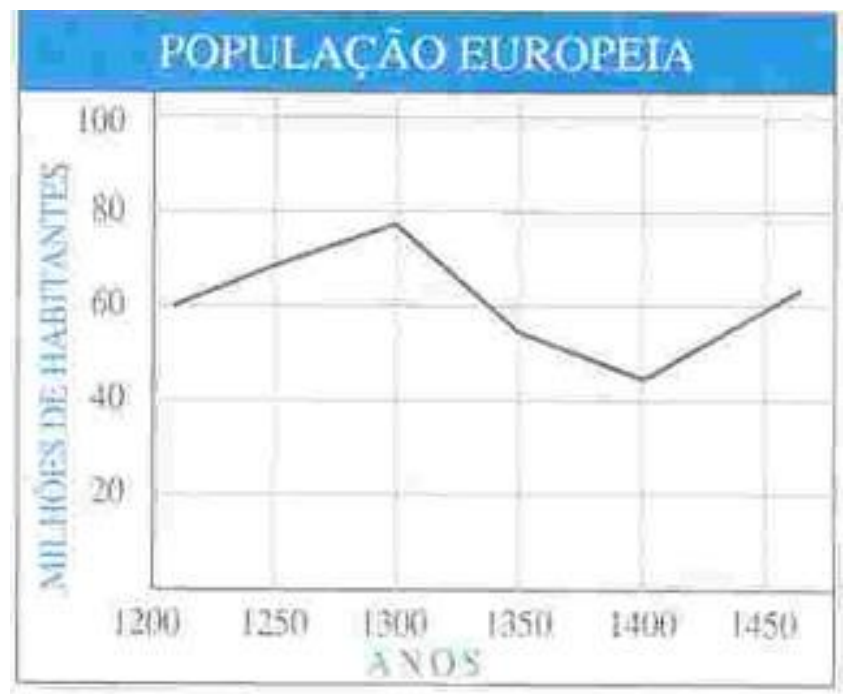

IMAGEM 1

http://historia8eb23dduarte.blogspot.com/2007/09/populao-europeia.html 
Só podemos fazer estimativas, dada a ausência de censos e de fontes com valor estatístico; as estimativas de Delort são razoáveis, embora inexatas: nem poderiam deixar de sê-las. A população europeia, entre 1300 e 1350, variava entre 60 e quase 80 milhões de pessoas - o número maior inclui a Hungria, a Polônia e a parte europeia do império bizantino; o número menor vivia na Europa ocidental. Delort localiza a tragédia demográfica europeia-ocidental entre fins da década de 1340 e início da seguinte. Mas a catástrofe foi mais longa, prolongando-se até cerca 1400, quando a população caiu de mais de 60 para cerca de 40 milhões. As estimativas confirmam que um terço da população da Europa ocidental morreu da peste na segunda metade do século XIV, o que equivale a 20 milhões de mortos.

Se a Peste Negra foi a pandemia mais devastadora da história universal, como afirma Delort, veremos no transcorrer deste artigo. Mas é sabido que o flagelo desta peste foi aterrador. Trata-se de uma doença bacteriana, provada por um bacilo em forma de bastonete. A doença é inoculada por mordeduras de pulgas, em geral hospedeiras de roedores já contaminados. Ao picarem humanos, as pulgas transmitem a Yersínia pestis, nome científico da bactéria em causa, que penetra na pele e se desloca para os vasos linfáticos, derrota os linfócitos que defendem o organismo humano e, quando alcança o pulmão, mata o infectado em cerca de dez dias.

Neste seu artigo, Delort esmiúça o mundo dos roedores, em especial as ratazanas contaminadas pela bactéria bubônica, cujo vetor foi a pulga - podemos dizer que a dupla ratazana-pulga fez uma parceria nesta praga. As ratazanas, no entanto, também morriam, e a abundância de ratazanas mortas nas cidades medievais tornava-se logo um indício de que a peste havia chegado. Delort destaca a ratazana preta, chamada Rattus rattus, como o maior vetor da peste entre os roedores (DELORT, 1985: p.111). Este tipo de ratazana costuma andar em grupos, um macho e algumas fềmeas, tendo preferência por formar ninhos em sótãos, forros de casas, frestas de muros, armazéns, porões de navios, zonas portuárias. Trata-se de uma ratazana sobretudo urbana, à diferença das ratazanas acastanhadas, preferencialmente rurais. Mas também estas transmitiram, através das pulgas, a peste europeia do século XIV.

As características da ratazana preta combinam com o que se conhece da Peste Negra. Atacou sobretudo as cidades e vilas, onde havia aglomeração de pessoas, e chegou pelo Mar Mediterrâneo, escoadouro das rotas marítimas que traziam as 
especiarias da Índia ou da China para a Europa, seja pelo Mar Negro, seja pelo Mar Vermelho. Veneza, no Mar Adriático, e Gênova, no Mar Tirreno, eram as cidades italianas mais relevantes na importação e distribuição dessas mercadorias na Europa.

A rota da Peste Negra mais aceita pelos historiadores da Idade Média, destaca a Sicília, no sul da Itália, como porto de entrada, estimando outubro de 1347 como marco inicial da praga. Trazida por doze galeras genovesas, logo se espalhou pela ilha e alcançou a própria Gênova, Pisa e depois Veneza, em 1348. A península itálica, no século XIV, foi o epicentro europeu da Peste Negra, assim como no caso da pandemia da COVID-19 em 2020. Mas a epidemia se alastrou pela França, através de Marselha, seguindo as rotas do comércio interno medieval, terrestre ou marítimo. Portos marítimos e feiras interioranas, como as de Champanhe, na França, foram núcleos de irradiadores da grande peste.

Segundo Jean-Noël Biraben, especialista na história da Peste Negra na França e no Mediterrâneo, em curto ou médio prazo a peste causava violentos surtos nas cidades, a cada 8,10 ou 15 anos, que perderam até $40 \%$ de sua população. Ela persistiu depois, em estado quase endêmico, "vagando caprichosamente de uma rua ou de um bairro a outro, sazonalmente, durante um, dois e até cinco anos seguidos" (Apud DELUMEAU, 1989: p.108).

Eis um bom retrato do cotidiano da Peste Negra, responsável pelo surgimento da Ars Moriendi, um conjunto de textos ilustrados da literatura latina produzidos na primeira metade do século XV, empenhados em aconselhar os indivíduos na arte do "bem morrer", para lograr a salvação espiritual, que era para todos a mais importante. Mas desde o século XIV divulgou-se uma "cultura da morte", literária ou iconográfica, produzida ora pelas classes populares, ora pelas eruditas. Todas compartilhavam a “cultura da morte", para domesticá-la (ARIÈS, 1977: p.17-29) ou como expressão de um medo coletivo insuportável. 


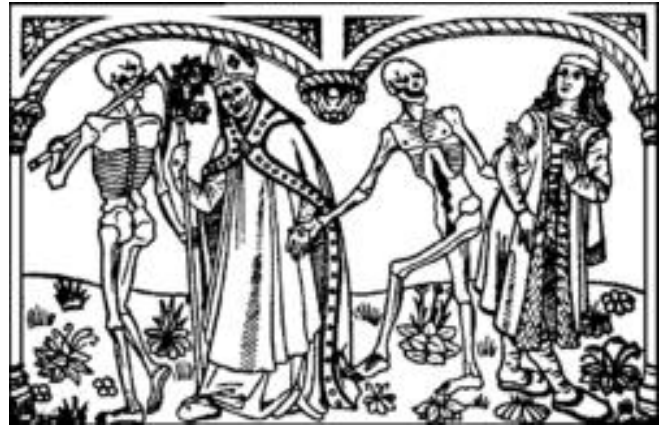

IMAGEM 2 - A Dança da Morte, xilogravura de Michael Wolgemut na Crônica da Crônica de Nuremberg, 1493. Domínio público. Disponível em:

https://pt.wikipedia.org/wiki/Dança_macabra\#/media/Ficheiro:Danse_macabre_by_Michael_Wolg emut.png

\section{A pandemia variólica na América}

A catástrofe demográfica que abateu as populações nativas das Américas oferece números estratosféricos. No México asteca, caso melhor conhecido, uma população estimada em cerca de 25 milhões de pessoas, na chegada de Cortez em 1519, mal passava de 1 milhão, em 1605 (SANCHEZ-ALBORNOZ, 1973: p.72). Bastaria isto para rebater a afirmação de Delort que a peste negra fora a "mais devastadora pandemia da história humana", ao menos quanto a número absoluto de óbitos No império incaico, cujos dados são mais imprecisos, no mínimo 15 milhões de nativos morreram de varíola no século XVI, inclusive o imperador Huaina Cápac, ainda antes da conquista liderada por Francisco Pizarro nos anos 1530 (WACHTEL, 197: p.59-61)).

A mortandade se alastrou por toda parte. Nas Antilhas, primeiro cenário do contato entre nativos e espanhóis, certas ilhas perderam toda a população indígena entre fins do século XV e primeiros anos do XVI. Poderíamos multiplicar os exemplos, lembrando que $90 \%$ da população nativa se concentrava em pouco mais de $5 \%$ da superfície continental, com destaque para a Mesoamérica e os Andes Centrais. A mortalidade da população nativa nessas regiões pode ter chegado ou ultrapassado a casa dos 50 milhões.

A elevada mortalidade foi pluriepidêmica, motivada por simples gripes que logo evoluíam para pleurisias ou pneumonias, "febres terçãs", como os portugueses denominavam a malária (que, em algumas regiões, tornou-se endêmica) e outras 
moléstias. Mas há consenso de que a varíola foi a maior vilã das populações nativas do continente nos anos 1500 .

No citado livro As doenças têm história, Pierre Darmon, assinou o artigo "A cruzada antivariólica", concentrando-se, porém, nas ações sanitaristas dos séculos XIX e XX, o que escapa ao escopo do presente texto. Mas vale dizer que a varíola é doença virótica, e não bacteriana, como a peste bubônica. Transmite-se pelo ar e pelo contato físico, alcança os pulmões e provoca pústulas na pele do infectado.

Há notícia em Tucídides sobre uma peste na Atenas do século V a.C., que alguns presumem ter sido variólica, responsável, entre outros fatores pelo declínio da pólis grega enquanto potência mediterrânica da época. Hipócrates, porém, não descreveu a doença, desconhecida até então, se é que se tratou de uma epidemia de varíola.

Salvo por este caso discutível, afirma-se que a varíola chegou à Europa levada pelos omíadas, que conquistaram a Península Ibérica no século VIII, e reapareceu com força a partir do século XI, em meio à Reconquista Cristã e ao incremento do comércio entre a Europa e o Oriente Próximo. Muitos presumem que a origem da varíola é asiática ou africana, mas não passam de especulações improváveis, mormente partindo de historiadores ocidentais. Na história das grandes epidemias é comum atribuir as origens da tragédia a grupos exteriores - o que, no caso europeu, é quase um consenso. No caso africano, como veremos, notícias de epidemias variólicas só aparecem relacionadas aos séculos XVII e XVIII, sendo as populações africanas vítimas, não vetores, das pestes.

Na Europa, a varíola tornou-se endêmica ao longo da Época Moderna, embora com letalidade relativamente baixa. Estima-se que 400 mil pessoas morreram de varíola no continente no século XVIII, o que, considerando uma população de 85 milhões de pessoas, na parte ocidental do continente, equivaleria a $0,5 \%$ de letalidade anual por esta causa.

Também é sabido que os europeus praticaram uma terapia mais ou menos eficaz contra a varíola, importada da China - o que parece confirmar que o Império do Meio chegou a ser epicentro da pandemia variólica entre a Idade Média e a Época Moderna ocidentais. O tratamento implicava raspar e pulverizar as feridas dos infectados e fazêlos inalar o pó. Era quase uma terapia de base empírica que, certamente, inspirou as 
experiências do inglês Edward Jenner, consideradas pioneiras na história da vacina antivariólica (ver nota 3$)$.

\section{4 - As bexigas no Brasil}

No Brasil quinhentista, a varíola foi implacável: matou milhares de nativos no século XVI. Ficou conhecida como peste das bexigas, pela fetidez das feridas exalada em doentes terminais. O Dicionário da Língua Portuguesa de Antônio Moraes Silva, cujo original data de 1789 , ofereceu dois significados para a palavra. O primeiro, válido até hoje, define bexiga como "bolsa membranosa que é reservatório de urina"; o segundo significado é o de "empola (bolha ou vesícula) que se forma sobre a cútis com humor acre e corrosivo, em geral usado no plural" (SILVA, 1813, vol. I: p.280). Este é o significado que aqui interessa.

O epicentro da peste das bexigas no litoral brasileiro foi a Bahia, a partir da década de 1560. Alexander Marchant, no clássico Do escambo à escravidão, menciona duas irrupções de varíola, entre 1562 e 1563, mas na realidade foram dois surtos da mesma epidemia (MARCHANT, 1980: p.102). O primeiro ocorreu no entorno da Bahia, em 1562, flagelando aldeamentos próximos a Salvador ou no recôncavo baiano, com duração de três a quatro meses. Pelo menos 30 mil nativos morreram neste surto. $\mathrm{O}$ segundo surto apareceu em Ilhéus, também em 1562, arrastou-se por cerca de um ano e atingiu a Bahia em 1563. Há menos dados sobre este segundo surto, mas um jesuíta afirmou que de cada vinte infectados, morriam doze. No aldeamento de Nossa Senhora d'Assunção, cerca de 25\% morreram numa população de 4 mil nativos.

A peste das bexigas agravou, dando continuidade a diversas epidemias irrompidas desde os anos 1550, como pleurites, gripes e febres terçãs - a malária, que em algumas regiões se tornou endêmica. Há notícias, nas cartas jesuíticas, de uma forte gripe que, em 1552, flagelou a população indígena em Pernambuco, região de ponta da nascente economia açucareira no litoral, à base da escravidão indígena. Há registro de uma doença inespecífica que se alastrou pelo Rio de Janeiro, em 1558. Outra epidemia, não se sabe qual, atacou a população tupiniquim de São Paulo, em 1560, poucos anos depois da fundação dos jesuítas em Piratininga. Mesmo antes de iniciar-se os descimentos de nativos para o litoral, a modo de cativá-los ou catequizá-los, há registro 
de epidemias anteriores à catástrofe variólica. No Rio de Janeiro, por volta de 1558, uma pleurite atacou a população tupinambá, alastrando-se pelo Espírito Santo. Estimase que 1/6 dos nativos morreram infectados. Neste caso, a epidemia ocorreu em região ainda não ocupada pelos portugueses; a pleurisia que alastrou na Guanabara possivelmente foi trazida pelos franceses, que fundaram a França Antártica em 1555. Ainda no tempo do escambo do pau-brasil entre nativos e portugueses ou franceses, moléstias fatais foram transmitidas a grupos nativos.

Mas não houve epidemia que se comparasse aos surtos variólicos ocorridos no litoral a partir de 1562. Eles se alastraram até a década de 1580, em ondas sucessivas, havendo registro de que a população nativa da Bahia caiu de cerca de 40 mil, em 1564, para 10 mil, em 1585 . Uma letalidade de $75 \%$ na região, ao logo de vinte anos, índice superior à letalidade da Peste Negra na Europa do século XIV.

Há controvérsias sobre a origem da varíola no litoral quinhentista. A opinião tradicional, por assim dizer, atribui as pestes de 1562 à chegada de um navio português com gente infectada. Mas os vetores da varíola eram portugueses? Difícil afirmá-lo com certeza e Marchant observou, com acuidade, que os relatos jesuíticos sobre a bexiga não mencionam vítimas lusitanas (MARCHANT, 1989: p.103). Possivelmente, os portugueses desembarcados em 1562 estavam já imunes, a confiar na hipótese lançada por Joseph Miller e Dauril Alden, em artigo de 1988, de título conclusivo: Unwanted cargoes: the origins and dissemination of smallpox via slave trade from Africa to Brazil. ${ }^{2}$

Neste artigo, incluso em livro sobre tráfico e intercâmbios entre a África e a América, Aldrin e Miller associam a entrada do vírus com o incremento do tráfico atlântico, quando grupos mais numerosos de africanos escravizados começaram a ser introduzidos no litoral. Agregam, em apoio a esta hipótese, a ausência de registros sobre as bexigas nas primeiras décadas de contato, o tempo do pau-brasil - apesar de ocorrerem, como afirmei antes, epidemias de outros tipos no litoral, antes mesmo da solução açucareira para a colonização do Brasil.

Trata-se de uma hipótese plausível, embora discutível, antes de tudo porque a varíola só se espalhou pelos nativos do litoral na década de 1560, momento de estruturação da economia açucareira e da catequese jesuítica - não antes, quando os contatos entre os grupos indígenas e os europeus era pontual. 
A contrariá-la, além da tradição ocidental em atribuir a origem de epidemias a outros povos ou continentes, menciono a obra do grande africanista Alberto da costa e Silva. Em A manilha e o libambo, o autor faz menção à varíola em apenas três situações: a uma epidemia que assolou o antigo reino de Monomotapa (no atual Moçambique), no meado do século XVII; a "novas formas de varíola" que, juntas a outras doenças, flagelaram as populações da África ocidental e centro-ocidental no decurso no curso do século XVII; a uma epidemia variólica no extremo-sul africano em 1715. Todas "trazidas da Europa, da Ásia e das Américas" (SILVA, 2002: p.668, 774 e 874).

Qual grupo cultural, qual continente levou a varíola para o litoral brasílico nos anos 1500? A tradicional hipótese do navio lisboeta de 1562 me parece mais credível. Mas não se trata, aqui, de identificar os agentes responsáveis pela disseminação da varíola entre os indígenas - se portugueses ou africanos - senão de considerar que, no sentido amplo, a varíola foi inoculada "no corpo do Brasil" - como diria Baeta Neves (NEVES, 1978: p.134) - a partir do povoamento luso-africano e da exploração da canade açúcar, uns senhores, outros escravos, e sobretudo por meio da catequese jesuítica. Na Idade Moderna, o triângulo Portugal-África-Brasil - fundador de uma identidade cultural atlântica, como afirmaram muitos, desde Gilberto Freyre, em Casa Grande \& Senzala (FREYRE, 1973) até a historiografia contemporânea (CALAINHO, 2008) - foi também decisivo para a dizimação, em grande escala, da população indígena no litoral brasílico.

A disseminação da varíola entre os grupos indígenas relaciona-se, também, a uma discussão clássica da historiografia brasileira. Fernando Novais, expoente de nossa historiografia desde os anos 1960, atribuiu a expansão da escravidão africana, em detrimento da indígena, aos interesses comerciais do tráfico atlântico (NOVAIS, 1979: p.98). Interesses inegáveis, pois os traficantes de africanos no Atlântico se beneficiavam muito mais, financeiramente, do que os traficantes de cativos indígenas nos sertões do Brasil. Em contraposição, Ciro Cardoso afirmou, desde os anos 1970, que a substituição do cativeiro indígena pelo africano no litoral do Brasil, como em outras partes do continente, deveu-se ao esgotamento da população indígena como manancial de mãode-obra para as lavouras coloniais (CARDOSO, 1975:p.65). 
A disseminação da varíola a partir da década de 1560 contribui para sustentar a posição de Cardoso, em especial porque o tráfico africano iniciou a arrancada exatamente neste século. Lateralmente, porém, permanece uma questão interessante, quase uma charada: foram os africanos escravizados que trouxeram a varíola que, ao destroçar a população nativa do litoral, estimulou a escravidão africana em substituição à indígena? Impossível responder com precisão, mas tais relações demonstram a complexidade os processos históricos e a inconsistência de explicações causais unívocas.

O certo é que a varíola se espalhou por todo o litoral, entre os indígenas, até fins do século XVI. Não exterminou a população nativa do litoral brasílico, como muitos afirmaram, mas reduziu-a drasticamente, tornando a região uma terra dos males sem fim (MAESTRI, 1995). Mas a peste perpetrou uma catástrofe demográfica entre os índios que, guardadas as proporções, é comparável ao que ocorreu no México Central e nos Andes Centrais no século XVI.

A varíola se espalhou, partindo da Bahia e de Ilhéus para as capitanias do norte, alcançando Pernambuco, e para as capitanias do sul, rumo ao Rio de Janeiro, ao Espírito Santo e ao planalto de Piratininga - vitimando o chefe Tibiriçá dos tupiniquins, aliado de João Ramalho, que os jesuítas consideravam uma "petra scandali da colonização vicentina", por ele desfrutar, graças à sua destreza guerreira, de várias esposas nativas. João Ramalho morreu com mais de 80 anos, vereador da Câmara de São Paulo. Morreu de velho, pois jamais foi alcançado por quaisquer epidemias.

A correspondência jesuítica constitui, sem dúvida, o manancial de fontes para o cotidiano da peste variólica que assolou a população do litoral brasílico. Em carta enviada ao provincial da Companhia em Portugal, datada de 30 de maio de 1564, padre Antônio Blasquez escreveu que os nativos eram tomados por um "fogo no coração", referindo-se às febres que o vírus causava nos infectados, matando em cerca de duas semanas, após espalhar pústulas e lesões na face, nas mãos e nos pés. Descreveu as feridas como "tão asquerosas e hediondas que não havia quem as pudesse suportar com a fetidez que delas saía" (LEITE, 1931: p.406). Padre Pedro da Costa, escrevendo do Espírito Santo aos padres de Lisboa, em 1565, afirmou que "as bexigas eram tão nojosas e de tão grandes fedores que punham espanto, e muitas vezes se estava arrenegando a carne de podre". (LEITE, 1931: p.456). Os jesuítas descreveram, de fato, 
os hoje reconhecidos sintomas da varíola, que se inicia com febres, dores musculares e náuseas, indício da infecção do trato respiratório e, alcançando a corrente linfática, provoca feridas na pele, a começar pela boca.

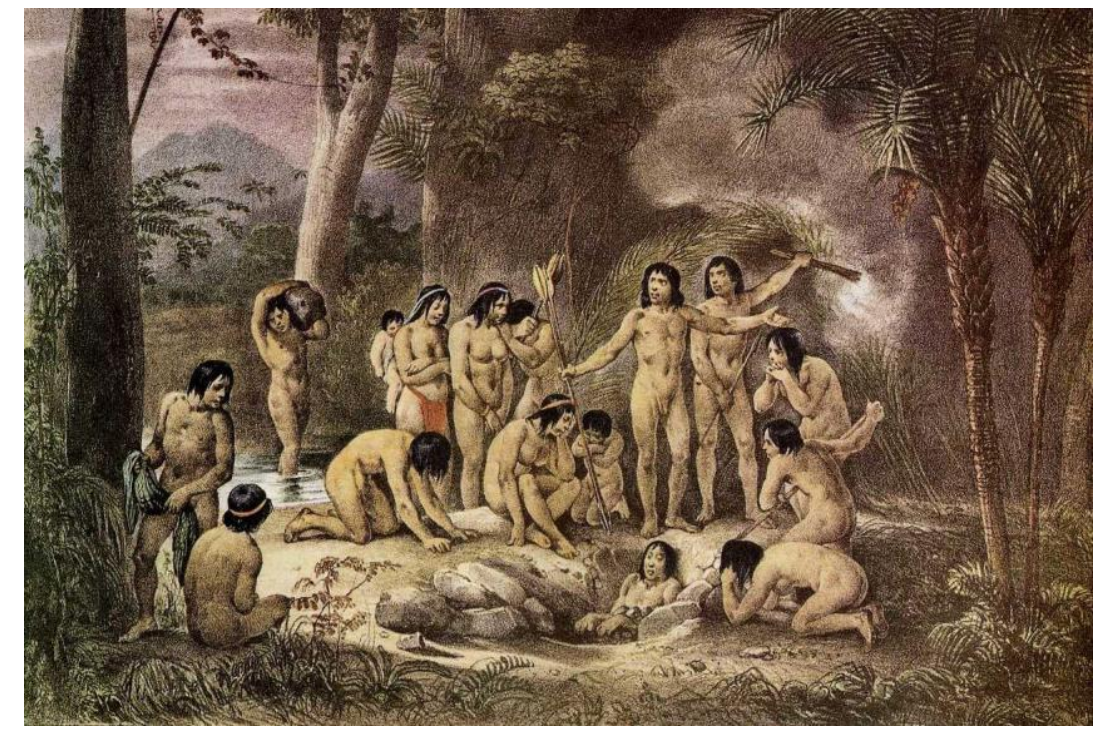

IMAGEM 3 - Sepultamento de um índio. Litografia de Joahan Moritz Rugendas, Viagem pitoresca através do Brasil, 1835.

http://baraoemfoco.com.br/barao/portal/cultura/fotografia/Moritz-Rugendas/moritz-rugendas$\underline{6 . h t m}$

A imagem acima é meramente ilustrativa do enterramento de um índio, provavelmente tapuia, registrado pelo alemão J. Moritz Rugendas, no século XIX. Ela não dá conta minimamente, do que se passava com os infectados pela varíola no século XVI.

A imagem abaixo é registro mais realista dos efeitos da doença na pele, em particular das pústulas que se espalhavam pelo corpo dos infectados. 


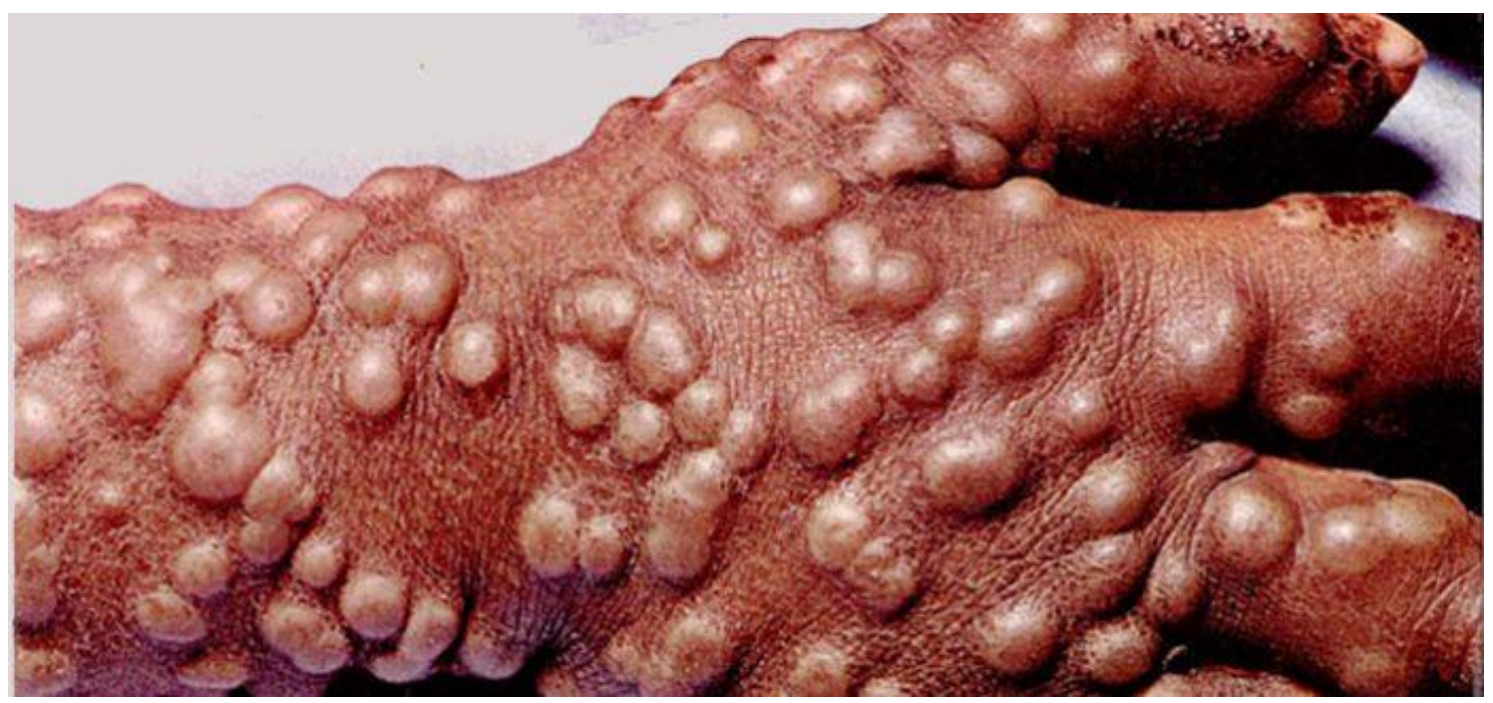

IMAGEM 4 - Pústulas na mão de um infecto pela varíola em estágio avançado https://opas.org.br/tudo-sobre-variola-o-que-e-sintomas-tratamento-prevencao-e-mais/

A correspondência, esta sim, registra as cenas cotidianas de horror. O grito dos doentes, o amontoado de cadáveres que, mal enterrados, eram comidos aos poucos por porcos e outros bichos, o pavor generalizado. Informa, ainda, o esforço dos inacianos em cuidar dos infectados por meio de sangrias, laranja ou açúcar, no início para tentar curá-los e, depois, para ao menos amenizar o sofrimento dos moribundos. Tudo em vão. Até hoje o saber médico "não reconhece a existência oficial de qualquer cura ou terapêutica capaz de eliminar o vírus, aconselhando-se estratégias terapêuticas que atuam sobre os sintomas, corrigindo a desidratação do organismo e as infecções secundárias decorrentes das erupções cutâneas e das pústulas" (ROQUE, 2004: p.184). ${ }^{3}$ Naquela época, como já disse, sequer havia uma terapêutica minimamente eficaz para a doença.

Não por acaso foram os jesuítas que melhor e mais fartamente registraram as pestes das bexigas no século XVI. Antes de tudo, eram deles os principais relatos do dia-dia da colonização, se comparados às crônicas ou fontes administrativas, mas principalmente porque a peste encontrou nos aldeamentos o cenário perfeito para se alastrar. Muito mais do que nas lavouras nascentes de cana-de açúcar, que empregavam, no máximo, algumas dezenas de índios cativos.

Em seu estudo sobre a escravidão e a economia açucareira na Bahia, Stuart Schwartz afirmou que, nos anos 1550 e 1560, quase não havia escravos africanos nos engenhos baianos, e cerca de dois mil nos 66 engenhos pernambucanos. No engenho 
São Pantaleão do Monteiro, em 1577, dos 40 escravos nomeados em inventário, 2/3 eram indígenas, ou seja, cerca de 26. Os engenhos do litoral só excepcionalmente alcançavam o número de 100 escravos, entre africanos e nativos, com largo predomínio de indígenas até fins do XVI. Nos inventários relativos ao engenho de Sergipe do Conde, um dos principais da Bahia, havia 51 escravos nativos contra apenas nove africanos em 1572 - números que caíram, respectivamente, para 15 e 7 em 1591, após as ondas das bexigas (SCHWARTZ, 1988: p.68).

O que pretendo indicar, com esses dados, não é tanto o largo predomínio da escravidão dos nativos nos engenhos baianos e pernambucanos até as últimas décadas do século XVI, mas o quantitativo médio de cativos indígenas por engenho, oscilando na casa de poucas dezenas. Além dos cativos, em razão da ação jesuítica contra o cativeiro, o número de trabalhadores indígenas podia crescer, e muitas vezes eram falsamente arrolados como escravos, nos inventários, mas isto não altera o modesto número de nativos agrupados nas lavouras e engenhos coloniais no século XVI.

Em contraposição, os aldeamentos da Companhia de Jesus abrigavam milhares de índios. Nas décadas de 1550 e 1560, os jesuítas fundaram doze aldeamentos, o menor dos quais - o de Santo Antônio - possuía 2 mil nativos reduzidos. Entre 1559 e 1583, 5 mil índios foram ali batizados, o que presume estimar uma população de 60 mil aldeados nas doze missões inacianas (SCHWARTZ, 1988: p.48).

Isto posto, não resta dúvida de que a irradiação da varíola ocorreu em escala muito superior nos aldeamentos do que nas lavouras e engenhos. Um grande paradoxo, pois a política inaciana de erigir aldeamentos no litoral, idealizada pelo provincial Manuel da Nóbrega e posta em prática nos anos 1556-57, provocou um agrupamento de índios fatal para esta população. A fundação de aldeamentos próximos aos núcleos de povoamento litorâneo, fiel ao ideal jesuítico de salvar a alma dos nativos pela catequese e combater a sua escravização, baseava-se na convicção de que, retirados dos sertões e sujeitos a uma nova disciplina em um espaço cristão, os indígenas teriam a sua salvação favorecida. Salvação espiritual, vale dizer, porque o agrupamento de milhares de homens, mulheres, idosos e nativos em espaço exíguo favoreceu, antes, a mortandade generalizada.

Muitos deles mal haviam chegado às missões, após descidos dos sertões e, antes mesmo de serem batizados, logo contraíam a peste. Padre Leonardo do vale, em carta 
escrita da Bahia para o companheiro Gonçalo Vaz, em 1563, contou que a elevada mortalidade estimulou o aumento prestígio dos pajés-açus, que na tradição tupinambá possuíam o dom de falar com os espíritos dos ancestrais ou mesmo de encarná-los. Os curandeiros, que o inaciano chamava de feiticeiros, condenavam a catequese, a começar pelo batismo, dizendo que era ele que produzia tantas mortes. Não é de surpreender que assim dissessem, considerando que milhares recebiam o batismo in extremis, já em fase terminal da doença, falecendo logo depois. Os padres retorquiam, acusando os feiticeiros indígenas de serem os responsáveis pela desgraça, acusando-os de promover “carnalidades e vícios" diabólicos, provocando assim o "castigo de Deus" (LEITE, 1931: p.382-386).

No cotidiano dos aldeamentos quinhentistas, travava-se uma disputa entre discursos religiosos rivais entre padres e pajés, enquanto a peste dizimava milhares de nativos. Em todo caso, a cronologia da irradiação da varíola no litoral quinhentista coincide com a da expansão dos aldeamentos jesuíticos. Coincidência no tempo e no espaço, como indica o mapa abaixo. 


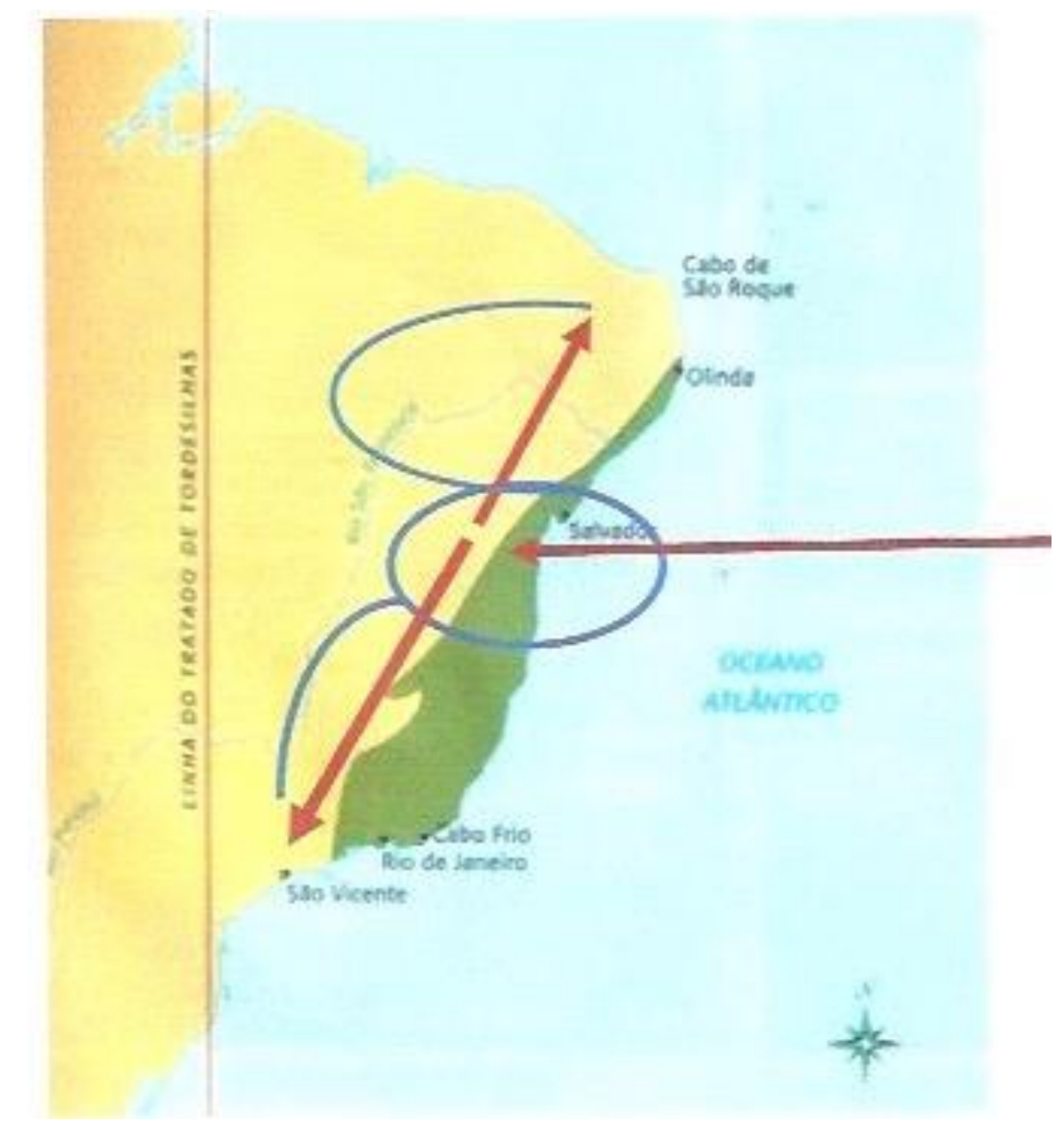

IMAGEM 5 - VARÍOLA E CATEQUESE NO LITORAL QUINHENTISTA

Mapa elaborado pelo autor.

Em vermelho, a rota da varíola, que veio do Atlântico para a Bahia, seja de Lisboa ou de algum porto africano envolvido no tráfico de escravos, e dali seguiu para o norte, na direção de Pernambuco, e para o sul, rumo a São Vicente. Em azul, os caminhos da catequese nos aldeamentos inacianos, nucleado na Bahia e irradiando para para as capitanias do norte e do sul. Dois processos entrelaçados.

No caso do Brasil, multiplicaram-se as fugas de indígenas do litoral para as matas do sertão, fossem cativos ou aldeados, movimento registrado por vários cronistas de diferentes procedências no século XVI. Se até o final do século XV as populações de língua tupi tinham se estabelecido no litoral atlântico da América do Sul, através de várias rotas, a partir dos anos 1560 o sentido das migrações se inverteu. A busca da Terra sem Mal, um horizonte utópico da tradição tupi-guarani que estimulava a 
descoberta de um país mítico, onde viviam os ancestrais e a abundância de víveres era absoluta, foi redirecionada para o interior da terra brasílica.

Foram os próprios jesuítas, sempre atentos, os que mais registraram tais movimentos migratórios, insuflados por pregações de grandes pajés, embora diversos cronistas laicos também tenham registrado o processo. Mas foram os inacianos que passaram a chamar tanto as cerimônias exortatórias como os movimentos delas resultantes de santidades. Por mero acaso, a Inquisição Portuguesa produziu precioso acervo documental sobre a principal santidade indígena da Bahia quinhentista, localizada nas matas do Recôncavo Baiano, na década de 1580. Digo por caso em razão de o visitador do Santo Oficio lisboeta ter chegado ao Brasil, em 1591, para perseguir cristãos-novos, blasfemos e outros desviantes do catolicismo oficial, não para investigar cerimônias tupinambás - que, por sinal, desconhecia por completo (VAINFAS, 1995).

Maria Isaura Pereira de Queiróz foi uma dos etnólogos e antropólogos - muito antes dos historiadores - a registrar que, no século XVI, "profetas indígenas iam de aldeia em aldeia apresentando-se como a reencarnação de heróis tribais, incitando os índios a abandonar o trabalho e a dançar", pois chegariam os novos tempos "que instalariam na terra uma espécie de Idade de Ouro". (QUEIRÓZ, 1977: p.165). Na verdade, não se tratou exatamente da chegada a um tempo ou lugar novos, senão do retorno às ancestralidades e espacialidades tradicionais. Tempos e espaços míticos, portanto, mas porosos, penetrados pela história - jamais imutáveis - sobretudo pelo flagelo da varíola trazida pela colonização.

Santidades indígenas efervescentes, população indígena dizimada. Alguns autores afirmam ter ocorrido um autêntico genocídio da população indígena no início da colonização ibérica da América, quer a portuguesa, quer a espanhola. A mortalidade foi, de fato, absolutamente catastrófica.

\section{Conceito de genocídio em perspectiva histórica}

Não resta dúvida que a ideia de genocídio vem ao caso, em face desta tragédia demográfica das populações ameríndias em toda parte. Mas o genocídio em causa inspira-se no senso comum de assassinato de grupos culturais e/ou raciais inteiros por 
agentes históricos intolerantes e perversos? Ou há um conceito histórico e até institucional para definir genocídio?

Antes de tudo, o conceito de genocídio só apareceu no século XX, em 1942, proposto pelo jurista polonês de origem judaica, Raphael Lemkin. Lemkin se referia ao Holocausto judaico perpetrado pelo nazismo que, naquela altura, ainda era pouco conhecido nos países Aliados contra a Alemanha na Segunda Guerra mundial. Lemkin enxergou longe, deduzindo, apesar da propaganda falaciosa do III Reich, que a política nazista em face dos judeus era a de extermínio de todos os judeus europeus. Cerca de 6 milhões foram assassinados, mas o próprio regime nazista calculava que deveriam ser exterminados 11 milhões.

Lemkin definiu o genocídio como um crime de massa praticado contra indivíduos de determinada nação ou grupo étnico, não por quaisquer atos por eles praticados, mas por integrarem minorias odiadas pelo agente perpetrador. A ONU, como é sabido, inspirou-se em Lemkin, em 1946, ao definir o genocídio "negação do direito à vida de grupos humanos", particularizando os grupos étnicos, religioso ou político, reforçando esta definição em 1948, na Declaração Universal dos Direitos Humanos.

Muitos anos depois, em 2017, o historiador britânico John Cox seguiu a mesma linha, acrescentando que "o genocídio difere de outros crimes em massa contra a humanidade e atrocidades por sua ambição. O genocídio visa não apenas eliminar membros individuais do grupo alvo, senão apenas destruir a capacidade do grupo de manter sua coesão social e cultural” ( COX, 2017: p.17)

Uma variante do conceito de genocídio foi desenvolvida pelo camaronês Achille Mbembe, em 2003, atualmente muito citado nas Ciências Humanas. Mbembe parte do pressuposto de "que a expressão máxima da soberania reside em grande medida, no poder e na capacidade de ditar quem pode viver e quem deve morrer [...]. O Estado de exceção e a relação de inimizade tornaram-se a base normativa do "direito de matar", justificando o extermínio de outrem (MBEMBE, 2016: p.128) Trata-se do conceito de necropolítica. Segundo Mbembe, a necropolítica depende de uma intenção de algum Estado em exterminar minorias.

Pois bem, é impossível demonstrar que as coroas ibéricas formularam qualquer projeto de extermínio das populações nativas. Pelo contrário, por pressão da Igreja, em 
particular das ordens religiosas, decretaram leis de proteção aos índios, livrando-os do escravismo em nome de sua salvação espiritual. Religião à parte, as coroas ibéricas, bem como os conquistadores, colonos e eclesiásticos, tencionavam fazer dos nativos a mão de obra essencial da colonização, até onde fosse possível. Isto posto, não cabe o conceito de genocídio, tampouco o de necropolítica.

No entanto, considerando a mortandade de milhões de nativos ameríndios no século XVI, não haveria algum problema com o conceito? Penso que os historiadores devem se ancorar em conceitos para contar e explicar a história. Mas se ficarem cativos de conceitos de matriz teórica e conceitual, pode bem ocorrer que a realidade seja escondida. A peste variólica na América quinhentista não foi perpetrada intencionalmente pelas coroas ibéricas no século XVI, mas não teria ocorrido sem os contatos entre portugueses ou espanhóis e as populações nativas, prelúdio da colonização ibérica.

Fico na dúvida em afirmar que houve genocídio, do ponto de vista conceitual ou institucional. Mas, pensando na tragédia demográfica causada pelo colonialismo europeu, o genocídio é eloquente. A conclusão é um conselho para que os historiadores não fiquem escravizados pelos conceitos, não raro enganosos nas Ciências Humanas, e apostem mais na realidade factual, quantitativa e qualitativa. A tragédia das populações indígenas da América, causada pela varíola, foi, esta sim, a pandemia mais devastadora da história universal.

\section{REFERÊNCIAS}

ARIÈS, Philippe. História da morte no Ocidente. Rio de Janeiro: Francisco Alves, 1977.

AULDRIN, Dauril \& MILLER, Joseph. Unwanted cargoes: the origins and dissemination of Smallpox via slave trade from Africa to Brazil. In: KIPLE, K. F. The African exchange. Durham: Duke University Press, 1988, p.34-109

CALAINHO, Daniela. Metrópole das mandingas. Religiosidade negra e Inquisição Portuguesa no Antigo Regime. Rio de Janeiro: Garamond, 2008.

CARDOSO, Ciro. Sobre os modos de produção coloniais na América. In: SANTIAGO, Théo. América colonial. Rio de janeiro: Pallas, 1975, p. 61-68. 
CLARK, Stuart. French Historians and Early Modern Popular Culture. Past \& Present, 6:, 1983, 62-99.

COX, John. To Kill a People: Genocide in the Twentieth Century, 2a. ed. New York: Oxford University Press, 2017.

DARMON, Pierre. A cruzada antivariólica. In: LE GOFF, J. et al. (orgs). As doenças têm história. Lisboa: Terramar, 1985, p.305-321.

DELORT, Robert. Que a peste seja o rato. In: LE GOFF, J. et al. (orgs). As doenças têm história. Lisboa: Terramar, 1985, p.109-126.

DELUMEAU, Jean. História do medo no Ocidente. São Paulo: Companhia das Letras, 1989.

LE GOFF, Jacques et al. (orgs). As doenças têm história. Lisboa: Terramar, 1985.

LEITE, Serafim (org.). Cartas avulsas (1550-1568). Rio de Janeiro: Academia Brasileira de Letras, 1931.

FREYRE, Gilberto. Casa Grande \& Senzala (1933). 16a . ed. Rio de Janeiro: José Olympio, 1973.

MAESTRI, Mário. Os senhores do litoral. Conquista portuguesa e agonia tupinambá no litoral brasileiro. Porto alegre: EDUFRS, 1995.

MARCHANT, Alexander. Do escambo à escravidão. São Paulo: Companhia Editora Nacional, 1980.

NEVES, Luís F. Baeta. O combate dos soldados de Cristo na Terra dos Papagaios. Rio de Janeiro: Forense Universitária, 1980.

NOVAIS, Fernando. Portugal e Brasil na crise do antigo Sistema Colonial. São Paulo: HUCITEC, 1979.

MBEMBE, Achille. Necropolítica. Artes e ensaios 32, 2016, p.123-151

QUEIRÓZ, Maria Isaura. O messianismo no Brasil e no mundo. $2^{\mathrm{a}}$. Ed. São Paulo: AlfaÔmega, 1977.

ROQUE, RICARDO. Sementes contra a varíola: Joaquim Vás e a tradução científica das pevides de bananeira brava em Goa, Índia (1894-1930). História, Ciências, Saúde-Manguinhos 11, 2004 p.183-222,

SANCHEZ-ALBORNOZ. La población de América Latina. Madrid: Alianza Editorial, 1973, p.72.

SCHWARTZ, Stuart. Segredos internos. Engenhos e escravos na sociedade colonial. São Paulo: Companhia das Letras, 1988. 
SILVA, Alberto da costa e. A manilha e o libambo. África e a escravidão. Rio de Janeiro: Nova Fronteira, 2002.

SILVA, António de Moraes. Dicionário da Língua portuguesa. 2a . Ed. Lisboa: Typografia Lacérdina, 1813.

VAINFAS, Ronaldo. A heresia dos índios. Catolicismo e rebeldia no Brasil colonial. São Paulo: Companhia das Letras 1995.

WACHTEL, Nathan. Los vencidos. Los indios del Perú frente a la conquista española. México, Fondo de Cultura, 1976.

\section{Notas}

1 - O presente artigo resulta de uma conferência proferida no Seminário Virtual Internacional de História Moderna. Sou grato ao CNPq e à FAPERJ pelo financiamento de minhas pesquisas. 2 - Tradução nossa: Cargas indesejáveis: origens e disseminação da varíola através do tráfico de escravos da África para o Brasil.

3 - Jenner, observando mulheres que ordenhavam vacas, e se contaminavam com a chamada Cowpox, ficavam imunes à Smallpox, a varíola humana. Jenner inoculou o pus da ferida de uma ordenhadora contaminada de Cowpox em um menino de oito anos, infectado pela varíola humana e conseguiu curá-lo do vírus. A Revolta da Vacina ocorrida no Rio de Janeiro, em 1904, foi exatamente contra a campanha de vacinação obrigatória liderada pelo sanitarista Oswaldo Cruz. 